\title{
PENGARUH RISIKO KREDIT, MINIMALISASI RISIKO, PERTUMBUHAN PRODUK DOMESTIK BRUTO, DAN INFLASI TERHADAP PENDAPATAN BUNGA BERSIH PADA PERUSAHAAN PERBANKAN YANG TERDAFTAR DI BURSA EFEK INDONESIA PERIODE 2013-2016
}

\author{
Devi Widyawati \\ Deviwidyawati23@gmail.com \\ Universitas Ahmad Dahlan \\ Desta Rizky Kusuma \\ Kusuma.desta@gmail.com \\ Universitas Ahmad Dahlan
}

\begin{abstract}
ABSTRAK
The aim of this research is to examine empirically the impact of credit risk, risk aversion, gross domestic product (GDP) growth, and inflation to Net Interest Margin on banking companies enlisted in BEI year 2013-2016. The factors that influenced NIM is credit risk which is proxied with NPL (Non Performing Loan) ratio, risk aversion which is proxied with CAR (Capital Adequacy Ratio), GDP growth and inflation. The period used is from 2013-2016.This research is causal research, that is to find recausality of independent and dependent variable. The population is 42 banking companies. The sampling method used is purposive sampling method. Based on the criteria, there are 41 banking companies. The hypothesis trial is done by the analysis of data panel regression an before do it, the research did a classic assumption trial. The result of hypothesis trial is done partially is t-test showed that NPL has t-statistic score is 1,4136 and t-tabel score is 1,290 on alpha 10\%, so NPL has positive impact to NIM. CAR has t-statistic score is $-0,2698$ and t-tabel score is 1,290 on alpha $10 \%$, so CAR doesn't have impact to NIM. GDP growth has t-statistic score is 2,9349 and t-tabel score has 1,290 on alpha $10 \%$, so GDP growth has positive impact to NIM. Inflation has t-statistic $-0,5184$ and t-tabel score is 1,290 on alpha $10 \%$, so inflation doesn't have impact to NIM.
\end{abstract}

Keywords: Credit Risk, Risk Aversion, GDP growth, Inflation, Net Interest Margin.

\footnotetext{
PENDAHULUAN

Sebagai agen pembangunan, bank perlu memperhatikan kinerjanya, Gubernur Bank Indonesia (BI), Agus Martowardojo, mengungkapkan bahwa inflasi akhir tahun 2016 berada pada batas bawah 4 persen plus minus satu persen atau sesuai dengan target yang ditetapkan. Berdasarkan survei pada Oktober 2016, inflasi mengarah pada year on year (yoy) 3,2 persen. Pada tanggal 17 Maret 2016, Bank Indonesia memangkas BI rate sebesar 25 bps dari yang tadinya $7 \%$ menjadi $6,75 \%$ dengan deposite facility sebesar $4,75 \%$ dan lending facility sebesar
}

$7,25 \%$. Penurunan BI rate ini akan berdampak positif untuk pasar saham dan perekonomian. Pada Januari 2016, rasio kecukupan modal (Capital Adequacy Ratio/CAR) tercatat sebesar 21,5\%, sementara rasio kredit bermasalah (Non Performing Loan/NPL) berada di kisaran 2,7\% (gross) atau 1,4\% (net). Meskipun pelemahan ekonomi global dan domestik mengakibatkan kinerja korporasi di beberapa subsektor manufaktur dan sektor infrastruktur menurun, dampak penurunan kinerja korporasi tersebut pada ketahanan sistem perbankan relatif terbatas. Dari sisi fungsi intermediasi, pertumbuhan kredit tercatat sebesar $9,6 \%$ (yoy), sedikit 
menurun dari pertumbuhan bulan sebelumnya sebesar $10,4 \%$ (yoy). Pelonggaran kebijakan moneter, baik melalui penurunan BI rate dan GWM, yang mulai berdampak pada penurunan suku bunga perbankan, diperkirakan akan memperkuat likuiditas dan mendorong peningkatan pertumbuhan kredit perbankan. (Siaran Pers Rapat Dewan Gubernur, Desember 2016).

Bank Indonesia sebagai otoritas perbankan telah berupaya untuk menekan perbankan agar dapat menurunkan suku bunga kredit dan net interest margin ke tingkat yang wajar. Upaya ini terus di dengungkan dan didorong oleh Deputi Gubernur BI dalam setiap kesempatan teutama melalui bentuk himbauan moral (moral suasion) kepada para banker. Selain lewat moral suasion, BI juga akan memberlakukan regulasi terbaru yang mewajibkan bank untuk mengumumkan prime lending rate nya di media massa. Tujuannya adalah agar terjadi transparansi dalam kebijakan penetapan suku bunga kredit bank serta diharapkan dapat menurunkan tingkat suku bunga kredit dan NIM ke level yang wajar.

Rasio pendapatan bunga bersih atau net interest margin (NIM dapat digunakan sebagai acuan untuk menentukan strategi investasi bank dan investor. Net interest margin merupakan salah satu indikator profitabilitas bank, khususnya dalam usaha menghasilkan pendapatan bunga. Tingginya imbal hasil yang didapatkan dari pemberian kredit serta masih rendahnya proporsi pendapatan yang berasal dari fee based income membuat bank-bank di Indonesia mengandalkan net interest margin untuk memperoleh profitabilitas yang tinggi, sehingga perbankan harus menjaga agar rasio net interest margin tetap pada posisi yang tinggi.

\section{Rumusan Masalah}

1. Apakah Risiko Kredit berpengaruh positif terhadap Pendapatan Bunga Bersih pada perusahaan perbankan yang terdaftar di Bursa Efek Indonesia (BEI) periode 20132016 ?

2. Apakah Minimalisasi Risiko berpengaruh positif terhadap Pendapatan Bunga Bersih pada perusahaan perbankan yang terdaftar di Bursa Efek Indonesia (BEI) periode 2013- 2016?

3. Apakah Pertumbuhan Produk Domestik Bruto berpengaruh negatif terhadap Pendapatan Bunga Bersih pada perusahaan perbankan yang terdaftar di Bursa Efek Indonesia (BEI) periode 20132016 ?

4. Apakah Inflasi berpengaruh terhadap Pendapatan Bunga Bersih pada perusahaan perbankan yang terdaftar di Bursa Efek Indonesia (BEI) periode 2013-2016?

\section{REVIEW LITERATUR DAN HIPOTESIS}

\section{Landasan Teori \\ Risiko Perbankan}

Risiko perbankan adalah berfokus pada masalah financial karena bisnis perbankan adalah bisnis yang bergerak di bidang jasa keuangan. Bank menyediakan fasilitas yang mampu memberikan kemudahan kepada public sebagai nasabahnya untuk memperlancar segala urusan yang menyangkut dengan masalah keuangan. Karena fungsinya sebagai mediasi, bank harus mampu menyediakan atau memberikan kemudahan, seperti keamanan simpanan, kemudahan menarik kembali dana dalam jumlah yang disesuaikan, kemudahan dalam urusan mencairkan kredit termasuk rendahnya biaya administras yang ditanggung, suku bunga kredit yang rendah dan diperhitungkan yang dilakukan secara cepat dan akurat.

\section{Risiko Kredit}


Risiko kredit (Credit Risk) sering disebut juga risiko gagal tagih (default risk) yaitu risiko yang dihadapi karena ketidakmampuan nasabah dalam membayar bunga kredit dan mencicil pokok pinjaman. Ayuningrum (2011) mengungkapkan bahwa credit risk adalah risiko yang dihadapi bank karena menyalurkan dananya dalam bentuk pinjaman terhadap masyarakat. Risiko ini semakin besar, apabila bank umum tidak mampu meningkatkan atau memperbaiki kualitas kredit yang disalurkan. Rasio keuangan yang digunakan sebagai proksi terhadap nilai suatu risiko kredit adalah Non Performing Loan (NPL). Rasio ini digunakan untuk mengukur kemampuan bank dalam menangani risiko kegagalan pengembalian kredit oleh debitur.

NPL yang tinggi akan memperbesar biaya, sehingga berpotensi terhadap kerugian bank. Semakin tingi rasio ini maka akan semakin buruk kualitas kredit bank yang menyebabkan jumlah kredit bermasalah semakin besar dan oleh karena itu bank harus menanggung kerugian dalam kegiatan operasionalnya sehingga berpengaruh terhadap penurunan laba (ROA) yang diperoleh bank. Kredit dalam hal ini adalah kredit yang diberikan kepada pihak ketiga tidak termasuk kredit kepada bank lain.

\section{Minimalisasi Risiko}

Minimalisasi risiko atau Risk aversion merupakan suatu istilah yang memandang bank sebagai lembaga yang bersikap risk averse sebagai perantara antara pasar kredit dengan pasar dana pihak ketiga. Dalam kondisi risk averse (tidak menyukai resiko), maka semakin tinggi resiko yang dihadapi oleh bank, maka kompensasi marjin terhadap resiko tersebut juga akan semakin besar, begitu juga dengan kondisi sebaliknya.

Risk aversion diproksikan dengan rasio kelebihan modal yang dimiliki bank dari persyaratan modal minimum terhadap total asset (CAR). Jika risk aversion meningkat maka CAR juga mengalami kenaikan. Hal ini mengakibatkan resiko atas aktiva yang beresiko mengalami penurunan, sehingga profitabilitas bank meningkat dan seterusnya NIM juga akan meningkat. Capital Adequacy Ratio (CAR) adalah rasio kecukupan modal bank atau merupakan kemampuan bank dalam permodalan yang ada untuk menutup kemungkinan kerugian di dalam perkreditan.

\section{Efficiency Ratio}

Rasio Efisiensi (Efficiency Ratio)
merupakan ukuran peruasahaan dengan menggunakan asetnya untuk menghasilkan pendapatan. Rasio efisiensi dapat menghitung omset piutang, pelunasan kewajiban, jumlah dan penggunaan ekuitas, dan penggunaan umum persediaan dan mesin. Rasio ini juga dapat digunakan untuk menganalisis kinerja bank dan investasi.

Analisis menggunakan rasio efisiensi juga dikenal sebagai rasio aktivitas, yaitu untuk mengukur kinerja perusahaan jangka pendek. Beberapa rasio efisiensi antara lain, yaitu perputaran piutang, perputaran asset tetap, hutang terhadap rasio penjualan, dan rasio perputaran saham.

\section{Loan to Deposito Ratio (LDR)}

Menurut Dendawijaya (2005) Loan to Deposit Ratio (LDR) menyatakan seberapa jauh kemampuan bank dalam membayar kembali penarikan dana yang dilakukan deposan dengan mengandalkan kredit yang diberikan sebagai sumber likuiditasnya. Jika bank dapat menyalurkan seluruh dana yang dihimpun memang akan menguntungkan, namun hal ini terkait resiko apabila sewaktu-waktu pemilik dana menarik dananya atau pemakai dana tidak dapat mengembalikan dana yang dipinjamnya, begitu pula sebaliknya.

\section{Pertumbuhan Aset (LnSIZE)}


Lognormal Pertumbuhan Asset (LNSIZE) atau ukuran bank merupakan suatu variabel yang digunakan untuk mengukur skala ekonomi. Pada sebagian besar studi mengenai perbankan, total asset bank digunakan sebagai proxy. Ukuran bank memiliki hubungan yang positif dengan pendapatan bank sampai batas tertentu, dan akan memiliki dampak negatif apabila ukuran bank sangat besar, karena adanya birokrasi.

\section{Return on Asset (ROA)}

Return on Asset (ROA) merupakan merupakan rasio keuangan yang sering digunakan untuk mengukur keuntungan bersih yang diperoleh bank dari penggunaan asset bank. ROA merupakan kemampuan bank dalam menghasilkan laba berdasarkan total asset yang dimiliki.

\section{Giro Wajib Minimum (gwm)}

Peraturan Bank Indonesia nomor 12/19/PBI/2010, Bank Indonesia mendefinisikan GWM adalah jumlah dana minimum yang wajib dipelihara oleh bank yang besarnya ditetapkan oleh Bank Indonesia. Terdapat tiga jenis GWM dalam konteks perbankan di Indonesia. Pertama, GWM primer, yaitu simpanan minimum yang wajib dipelihara oleh bank dalam bentuk saldo rekening giro pada Bank Indonesia. Kedua, GWM sekunder, yaitu cadangan minimum yang wajib dipelihara dalam bentuk Sertifikat Bank Indonesia (SBI), Surat Utang Negara (SUN), SBSN. Ketiga adalah GWM LDR, yaitu simpanan minimum yang wajib dipelihara bank dalam bentuk saldo rekening giro pada Bank Indonesia sebesar persentase dari dana pihak ketiga yang dihitung berdasarkan selisih antara LDR yang dimiliki bank dengan LDR target.

\section{Ukuran Transaksi}

Ukuran transaksi atau Transaction size merupakan hasil refleksi dari total volume aktifitas yang dilakukan bank dalam penyaluran kredit yang diberikannya. Kredit yang diberikan bank mengandung resiko, sehingga dalam pelaksanaannya bank harus memperhatikan asas-asas perkreditan yang sehat. Dengan demikian, kondisi bank senantiasa dalam kondisi yang sehat.

\section{Pertumbuhan Produk Domestik Bruto} (PDB)

Pertumbuhan Produk Domestik Bruto (PDB) atau GDP Growth adalah nilai pasar semua barang dan jasa akhir yang diproduksi dalam perekonomian selama kurun waktu tertentu (Mankiw, 2003). GDP dapat diukur dengan dua cara: (1) sebagai arus produk jadi; (2) sebagai total biaya atau penghasilan dari input yang menghasilkan output. Karena laba merupakan hasil sisa, kedua pendekatan akan menghasilkan total GDP yang sama persis (samuelson dan Nordhaus, 2004). Semakin meningkatnya GDP per kapita masyarakat Indonesia telah menopang konsumsi domestik sehingga mampu memberikan pertumbuhan ekonomi nasional yang relatif tinggi. Untuk mengukur niai uang yang berlaku dari output perekonomian disebut GDP nominal, sedangkan GDP riil mengukur output yang dinilai pada harga konstan.

\section{Inflasi}

Inflasi adalah suatu proses meningkatnya harga-harga secara umum dan terus menerus. Dengan kata lain, inflasi juga merupakan proses menurunnya nilai mata uang secara terus menerus. Inflasi adalah proses dari suatu peristiwa, bukan tinggi rendahnya tingkat harga artinya tingkat harga yang dianggap tinggi belum tentu menunjukkan inflasi. Inflasi dianggap terjadi jika proses kenaikan harga berlangsung secara terus menerus dan saling mempengaruhi. Istilah inflasi juga digunakan untuk mengartikan peningkatan persediaan uang yang kadangkala dilihat sebagai penyebab meningkatnya harga. Tingkat inflasi telah diantisipasi pihak perbankan dengan baik, sehingga bank dapat melakukan penyesuaian tingkat suku bunga secara 
tepat guna menghasilkan laba dari selisih bunga bank. Peningkatan spread bunga bank akan berimbas pada meningkatnya NIM.

\section{Pendapatan Bunga Bersih}

Pendapatan Bunga Bersih atau Net Interest Margin (NIM) adalah rasio yang digunakan mengukur pendapatan bunga bersih yang dihasilkan oleh bank atau lembaga keuangan lainnya. Rasio NIM menunjukkan kemampuan manajemen bank dalam hal pengelolaan aktiva produktif sehingga dapat menghasilkan laba bersih. Pendapatan bunga bersih diperoleh dari pendapatan bunga dikurangi beban bunga. NIM mencerminkan risiko pasar yang timbul akibat berubahnya kondisi pasar, dimana hal tersebut dapat merugikan bank.

\section{Penelitian Terdahulu}

Dari beberapa hasil penelitian yang relevan mendukung teori yang dikemukakan diatas, maka berikut ini diantaranya yaitu, Menurut Sidabalok dan Viverita (2011), meneliti mengenai The Determinants of Net Interest Margin in the Indonesian Banking Sector, Hasil estimasi risiko kredit memberikan hasil yang secara statistik dan tegas, bahwa variabel tersebut mempengaruhi marjin bunga bersih. Tanda yang dihasilkan adalah positif. Kondisi ini sesuai dengan hasil penelitian oleh Brock dan Rojas (2000) dan mendukung teori bahwa semakin besar risiko kredit yang dihadapi bank, bank cenderung untuk mendefinisikan margin bunga bersih yang tinggi juga.

Menurut Kusumaningrum (2016), meneliti mengenai analisis faktor-faktor yang mempengaruhi net interest margin pada perusahaan perbankan yang terdaftar di BEI. Dalam penelitian ini menggunakan variable net interest margin (NIM), credit risk (NPL), efficiency ratio (BOPO), risk aversion (CAR), dan transaction size. Hasil penelitian ini menunjukkan Credit Risk yang diproksikan dengan Non Performing Loan (NPL) berpengaruh negatif terhadap net interest margin (NIM), efficiency ratio yang dihitung dengan rasio beban operasional terhadap pendapatan operasional (BOPO) berpengaruh negatif dan signifikan terhadap net interest margin (NIM), riskaversion diproksikan dengan capital adequacy ratio (CAR) berpengaruh positif dan signifikan terhadap net interest margin (NIM), dan transaction size yang dihitung dengan logaritma dari total kredit tidak berpengaruh terhadap net interest margin (NIM).

Menurut Azeez dan Gamage (2011), meneliti mengenai the determinants of net interest margin of commercial banks in sri lanka. Pengolahan data yang dilakukan yaitu menggunakan regresi SIB. Dalam penelitian ini, peneliti menggunakan variabel GDP growth yang menunjukkan adanya pengaruh negatif dan signifikan terhadap NIM.

Menurut Hidayat (2012), meneliti mengenai analisis pengaruh karakteristik bank dan inflasi terhadap net interest margin. Penelitian ini menggunakan metode purposive sampling sebanyak 29 bank sebagai sampel penelitian. Pengolahan data yang dilakukan yaitu menggunakan regresi data panel. Dalam penelitian ini, peneliti menggunakan variabel inflasi yang menunjukkan adanya pengaruh negatif dan signifikan terhadap NIM

\section{Hipotesis}

H1: Credit Risk berpengaruh positif terhadap Net Interest Margin pada perusahaan perbankan yang terdaftar di Bursa Efek Indonesia (BEI).

H2: Risk Aversion berpengaruh positif terhadap Net Interest Margin pada perusahaan perbankan yang terdaftar di Bursa Efek Indonesia (BEI).

H3: GDP growth berpengaruh negatif terhadap Net Interest Margin pada perusahaan perbankan yang terdaftar di Bursa Efek Indonesia (BEI). 
H4: Inflasi berpengaruh negatif terhadap Net Interest Margin pada perusahaan perbankan yang terdaftar di Bursa Efek Indonesia (BEI

\section{METODE PENELITIAN \\ Populasi dan Sampel}

Populasi dalam penelitian ini adalah seluruh bank konvensional yang terdaftar di Bursa Efek Indonesia sebanyak 42 bank didapat dari web Saham OK. Sampel adalah bagian dari jumlah dan karakteristik yang dimiliki oleh populasi tersebut. Sampel yang diambil dalam penelitian ini adalah perusahaan perbankan yang terdaftar di Bursa Efek Indonesia (BEI) dengan kriteria yang telah ditentukan.

Sampel dalam penelitian ini adalah sebagian dari bank konvensional yang terdaftar di Bursa Efek Indonesia, sebanyak 41 bank. Ada 1 bank yang tidak memenuhi kriteria yaitu, PT Bank Mestika Dharma Tbk, karena pada bank tersebut tidak memberikan laporan keuangan selama periode penelitian.

\section{Definisi Operasional}

Operasional variabel adalah penentuan construct sehingga menjadi variabel yang dapat diukur. Variabel itu sendiri menurut Sugiyono (2008) adalah suatu atribut, sifat atau nilai dari orang, obyek atau kegiatan yang mempunyai variasi tertentu yang ditetapkan oleh peneliti untuk dipelajari dan diambil suatu kesimpulan.

Dalam penelitian terdapat dua variabel yaitu variabel independen dan variabel dependen. Variabel independen adalah variabel yang tidak terikat oleh factor-faktor lain, tetapi mempunyai pengaruh terhadap variabel lain. Seperti yang dikemukakan oleh Sugiyono (2008), variabel dependen adalah variabel yang dipengaruhi atau yang menjadi akibat, karena adanya variabel bebas, sedangkan variabel independen adalah variabel yang memengaruhi atau yang menjadi sebab perubahannya atau timbulnya variabel dependen. Variabel dependen dalam penelitian ini adalah pendapatan bunga bersih atau net interest margin. Sedangkan variabel independen dalam penelitian ini yaitu risiko kredit atau credit risk yang diproksikan dengan non performing loan (NPL), minimalisasi risiko atau risk aversion yang diproksikan dengan capital adequacy ratio (CAR), pertumbuhan produk domestic bruto (PDB) atau GDP growth, dan inflasi.

\section{Teknik Analisis Data}

Analisis data mempunyai tujuan untuk menyampaikan dan membatasi penemuan hingga menjadi data yang teratur dan lebih berarti. Analisis data yang digunakan pada penelitian ini adalah analisis kuantitatif yang dinyatakan dengan angka-angka yang diolah menggunakan program Eviews.

\section{Statistik Deskriptif}

Menurut Sugiyono (2012) statistik deskriptif adalah statistik yang digunakan untuk menganalisa data dengan cara mendeskripsikan atau menggambarkan data yang telah terkumpul sebagaimana adanya tanpa bermaksud membuat kesimpulan yang berlaku untuk umum.

\section{Uji Asumsi Klasik}

Pengujian regresi linier dapat dilakukan setelah model dari penelitian ini memenuhi syarat-syarat yaitu lolos dari asumsi klasik. Syarat-syarat yang harus dipenuhi adalah data tersebut harus terdistribusikan secara normal, tidak mengandung heteroskedastisitas, autokorelasi dan multikolinieritas. Untuk itu sebelum melakukan pengujian regresi linier berganda perlu dilakukan lebih dahulu pengujian asumsi klasik, yang terdiri dari:

1. Uji Normalitas 
Pengujian normalitas memiliki tujuan untuk menguji apakah dalam model regresi, variabel pengganggu atau residual memiliki distribusi normal. Seperti diketahui bahwa uji $\mathrm{T}$ dan uji $\mathrm{F}$ mengasumsikan bahwa nilai residual mengikuti distribusi normal. Kalau asumsi ini dilanggar maka uji statistik menjadi tidak valid untuk jumlah sampel kecil. Untuk menguji normalitas data, penelitian ini menggunakan analisis grafik. Pengujian normalitas melalui analisis grafik adalah dengan cara menganalisis grafik normal probability plot yang membandingkan distribusi kumulatif dari distribusi normal. Uji statistik lain yang dapat digunakan untuk menguji normalitas residual adalah uji Jarque-Berra Jika hasil dari uji $\mathrm{J}-\mathrm{B}$ menunjukkan nilai prob. J-B di atas 0,05 maka data residual terdistribusi dengan normal.

\section{Uji Multikolinearitas}

Multikolinieritas adalah adanya suatu hubungan linier yang sempurna antara beberapa atau semua variabel independen. Uji multikolinieritas bertujuan untuk menguji apakah model regresi ditemukan adanya korelasi antar variabel bebas (independen). Model regresi yang baik seharusnya tidak terjadi korelasi diantara variabel bebas (Ghozali, 2006). Cara pengujian multikolinieritas pada penelitian adalah dengan nilai korelasi antar variabel independen dengan pengambilan keputusannya adalah bila nilai korelasi antar variabel independen > 0.85 maka terdapat multikolinieritas (Widarjono, 2013) Bila ada variabel independen yang terkena multikolinieritas, maka salah satu cara penanggulangannya adalah salah satu dari variabel yang terkena multikolinieritas tersebut dikeluarkan (Ghozali, 2006).

\section{Uji Heteroskedastisitas}

Uji heteroskedastisitas ini bertujuan untuk menguji apakah dalam model regresi terjadi ketidaksamaan varians dari residual satu pengamatan ke pengamatan lain. Jika varians dari satu pengamatan ke pengamatan yang lain tetap, maka disebut homoskedositas atau tidak terjadi heteroskedastisitas. Dan jika varians berbeda maka disebut heteroskedastisitas. Model regresi yang baik adalah yang homoskedastisitas atau tidak terjadi heteroskedasitas (Ghozali, 2006).

\section{Uji Autokorelasi}

Uji autokorelasi bertujuan untuk mengetahui apakah dalam suatu model regresi linier terdapat korelasi antara pengganggu pada periode $t$ dengan kesalahan pada periode t-1 (sebelumnya). Model regresi yang baik adalah regresi yang bebas dari autokeralsi (Ghozali, 2006). Alat analisis yang digunakan adalah uji DurbinWatson. Untuk mengetahui terjadi atau tidak autokorelasi dilakukan dengan membandingkan nilai statistik hitung Durbin Watson pada perhitungan regresi dengan statistik tabel Durbin Watson pada tabel.

\section{Regresi Data Panel}

Dalam pengujian analisis regresi terdapat tiga model yang bisa digunakan yaitu: ordinary least square atau common effect, fixed effect, dan random effect. Pada penentuan model akan digunakan uji Chow (redundant fixed effect test) dan uji Hausman (correlated random effect test) yang dibantu dengan menggunakan software statistic Eviews.

\section{Uji Hipotesis}

\section{Uji Parsial (Uji T)}

Uji t pada dasarnya menunjukkan seberapa jauh pengaruh satu variabel penjelas/independen secara individual dalam menerangkan variasi variabel dependen. Pengambilan keputusan penelitian ini diperoleh dengan cara membandingkan t-statistik masing masing variabel independen dengan $\mathrm{t}$ tabel (one-tail) pada tingkat alpha yang ditentukan. Apabila t-statistik lebih besar dari t-tabel (one tail) dengan arah 
yang sesuai maka hipotesis alternatif diterima yang artinya variabel independen tersebut berpengaruh secar signifikan terhadap variabel dependennya, dan begitu pula sebaliknya.

\section{Uji Koefisien Determinasi}

Uji $\mathrm{R}_{2}$ digunakan untuk menguji seberapa besar kemampuan model dalam menerangkan variasi variabel dependen. Nilai koefisien determinasi adalah antar nol sampai satu $\left(0<\mathrm{R}^{2}<1\right)$. Nilai $\mathrm{R}^{2}$ yang kecil berarti kemampuan variabel - variabel independen dalam menjelaskan variasi variabel dependen amat terbatas. Nilai yang mendekati satu berarti variabel-variabel independen memberikan hampir semua informasi yang dibutuhkan untuk memprediksi variasi variabel dependen (Ghozali, 2006).

\section{HASIL PENELITIAN DAN PEMBAHASAN}

\section{Statistik Deskriptif}

Data Statistik Deskriptif

\begin{tabular}{|r|c|r|r|r|r|}
\hline & $\mathrm{N}$ & Minimum & Maksimum & $\begin{array}{c}\text { Rata- } \\
\text { Rata }\end{array}$ & $\begin{array}{c}\text { Deviasi } \\
\text { Standar }\end{array}$ \\
\hline NIM & 164 & 0.24 & 9.65 & 4.9435 & 1.62006 \\
\hline NPL & 165 & 0.16 & 7.1 & 2.4772 & 1.53966 \\
\hline CAR & 163 & 8.02 & 48.38 & 18.8992 & 5.31733 \\
\hline GDP & 168 & 4.94 & 5.58 & 5.185 & 0.24285 \\
\hline INF & 168 & 3.02 & 8.38 & 5.7775 & 2.60289 \\
\hline $\begin{array}{r}\text { Valid N } \\
\text { (listwise) }\end{array}$ & 163 & & & & \\
\hline
\end{tabular}

Sumber : Data Sekunder, diolah (2017)

Dari tabel diatas dapat disimpulkan bahwa hasil uji analisis statistik deskriptif menunjukkan NPL (X1) memiliki nilai rata-rata (mean) sebesar 2,4772 dengan standar deviasi sebesar 1,53966. NPL tertinggi yaitu 7,10 dimiliki oleh Bank Harda Internasional Tbk dan yang terendah yaitu 0,16 dimiliki oleh Bank Mitraniaga Tbk. CAR (X2) memiliki nilai ratarata (mean) sebesar 18,8992 dengan standar deviasi sebesar 5,31733. CAR tertinggi yaitu 48,38 dimiliki oleh Bank Nationalnobu Tbk dan yang terendah yaitu
8,02 dimiliki oleh Bank Pembangunan Daerah Banten Tbk. GDP growth (X3) memiliki nilai rata-rata (mean) sebesar 5,1850 dengan standar deviasi sebesar 0,24285 . GDP growth tertinggi yaitu 5,58 dan yang terendah yaitu 4,94. inflasi (X4) memiliki nilai rata-rata (mean) sebesar 5,7775 dengan standar deviasi sebesar 2,60289 . Inflasi tertinggi yaitu 8,38 dan yang terendah yaitu 3,02. NIM (Y) memiliki nilai rata-rata (mean) sebesar 4,9435 dengan standar deviasi sebesar 1,62006. NIM tertinggi yaitu 9,65 dimiliki oleh Bank Pembangunan Daerah Banten Tbk dan yang terendah yaitu 0,24 dimiliki oleh Bank JTrust Indonesia Tbk.

\section{Uji Normalitas}

Tabel 2

Hasil Uji Normalitas

\begin{tabular}{|c|r|}
\hline Jarque-Bera & \multicolumn{1}{|c|}{ Probability } \\
\hline 4.163265 & 0,124726 \\
\hline
\end{tabular}

Sumber: Olah data Eviews, 2017.

Pada tabel di atas menunjukkan bahwa residual persamaan regresi pada uji normalitas tersebut berdistribusi normal. Hal ini ditunjukkan pada nilai prob. J-B sebesar 0,124726, yang mana lebih besar dari $5 \%(0,124726>0,05)$.

\section{Uji Autokorelasi}

Hasil Uji Autokorelasi

\begin{tabular}{|l|c|c|c|}
\hline R-squared & 0.05068 & $\begin{array}{c}\text { Mean dependent } \\
\text { var }\end{array}$ & 1.258052 \\
\hline $\begin{array}{l}\text { Adjusted } \\
\text { R-squared }\end{array}$ & 0.026646 & $\begin{array}{c}\text { S.D. dependent } \\
\text { var }\end{array}$ & 0.775769 \\
\hline $\begin{array}{l}\text { S.E. of } \\
\text { regression }\end{array}$ & 0.766178 & $\begin{array}{c}\text { Sum squared } \\
\text { resid }\end{array}$ & 92.75055 \\
\hline F-statistic & 2.108711 & Durbin-Watson & 1.843541 \\
\hline $\begin{array}{l}\text { Prob(F- } \\
\text { statistic) }\end{array}$ & 0.082206 & stat & \\
\hline
\end{tabular}

Sumber: Olah data Eviews, 2017.

Pada tabel 3 terlihat bahwa nilai Durbin-Watson stat adalah $1,8435, \mathrm{DL}=$ 1,6939 , DU $=1,7943$. Dengan demikian dapat disimpulkan bahwa DU $<1,8435<$ 4-DU yaitu menunjukkan tidak terjadi autokorelasi. 


\section{Uji Heteroskedastisitas}

Hasil Uji Heteroskedastisitas

\begin{tabular}{|l|c|c|c|}
\hline F-statistic & 0.905574 & Prob. F(12,150) & 0.543 \\
\hline Obs*R-squared & 11.01099 & Prob. Chi-Square(12) & 0.528 \\
\hline $\begin{array}{l}\text { Scaled explained } \\
\text { SS }\end{array}$ & 14.09955 & Prob. Chi-Square(12) & 0.294 \\
\hline
\end{tabular}

Sumber: Olah data Eviews, 2017.

Dari hasil pemeriksaan terhadap gejala heteroskedastisitas dengan uji White pada tabel 4 menunjukkan masing-masing nilai prob. Chi-Square pada Obs*Rsquared $0,528>0,05$. Maka uji heteroskedastisitas pada residual masingmasing regresi menunjukkan tidak terjadi heteroskedastisitas pada model regresi dengan variabel dependen NPL, CAR, GDP, INF terhadap variabel independen NIM.

\section{Uji Multikolinearitas}

\begin{tabular}{|c|c|c|c|c|}
\hline & NPL & CAR & GDP & INF \\
\hline NPL & 1.00000 & -0.16716 & -0.26579 & -0.27904 \\
\hline CAR & -0.16717 & 1.00000 & -0.18151 & -0.21465 \\
\hline GDP & -0.26579 & -0.18151 & 1.00000 & 0.54972 \\
\hline INF & -0.27904 & -0.21464 & 0.54972 & 1.00000 \\
\hline
\end{tabular}
Sumber: Olah data Eviews, 2017.
Uji multikolinearitas

dilakukan menggunakan metode korelasi antar variabel independen yaitu NPL, CAR, GDP, dan Inflasi. Terlihat pada tabel 4.9 nilai korelasi antar variabel independen NPL, CAR, GDP, dan inflasi < $90 \%$ atau 0,90, maka menunjukkan tidak adanya gejala multikolinearitas.

\section{Regresi Data Panel}

\begin{tabular}{|c|c|c|c|}
\hline Test Summary & Chi-Sq. Statistic & $\begin{array}{l}\text { Chi- } \\
\text { Sq. d.f. }\end{array}$ & Prob. \\
\hline Cross-section random & 0.000000 & 4 & 1.0000 \\
\hline
\end{tabular}

Dari hasil regresi data panel pada tabel 6 terlihat nilai prob. Cross section random sebesar $1,0000>0,05$, maka menunjukkan bahwa model random effect (GLS) yang digunakan dalam analisis regresi data panel.

\section{Uji Hipotesis}

Hasil Pengujian Pengaruh NPL, CAR, GDP, dan INF terhadap NIN

\begin{tabular}{|c|r|r|r|r|l|}
\hline Variable & Coefficient & Std. Error & t-Statistic & t-Tabel & Kesimpulan \\
\hline C & 0.6902 & 1.3668 & 0.5049 & & \\
\hline NPL & 0.0864 & 0.0611 & $1.4136^{*}$ & 1.29 & Terima H1 \\
\hline CAR & -0.0052 & 0.0194 & -0.2698 & 1.29 & Tolak H2 \\
\hline GDP & 0.8181 & 0.2787 & $2.9349^{*}$ & 1.29 & Tolak H3 \\
\hline INF & -0.0166 & 0.0320 & -0.5184 & 1.29 & Tolak H4 \\
\hline
\end{tabular}

Keterangan : * (signifikansi pada 10\%)

Pada tabel 7 dapat diketahui hasil pengaruh pengujian NPL, CAR, GDP, dan INF terhadap NIM. Pengambilan keputusan berdasarkan nilai t. hitung yang dibandingkan dengan one tail yang mana jika t. statistic > t tabel maka dapat disimpulkan terdapat pengaruh yang signifikan. Untuk dapat menerima hipotesis alternatif selain terdapatpengaruh yang signifikan, arah pengaruhnya juga harus sesuai dengan hipotesis.

Pada variabel credit risk (NPL) terhadap net interest margin (NIM) menunjukkan pengaruh positif yang signifikan yaitu $\mathrm{t}$. statistic $>\mathrm{t}$ tabel $(1,4136>1,290)$. Hal ini mengindikasikan bahwa semakin besar risiko kredit yang dihadapi bank, maka bank tersebut cenderung mendefinisikan margin bunga bersih yang tinggi juga.

Pada variabel risk aversion (CAR) terhadap net interest margin (NIM) menunjukkan yang berkebalikan dengan hipotesis. Risk aversion (CAR) terhadap net interest margin (NIM) menunjukkan tidak berpengaruh signifikan yaitu $t$. statistic < t tabel $(|-0,2698|<1,290)$. Hal ini mengindikasikan bahwa kenaikan rasio permodalan suatu bank bukan disebabkan karena adanya penambahan modal baru, tetapi pada umumnya karena disebabkan adanya penurunan risiko kredit sebagai dampak dari pelunasan kredit yang dilakukan peminjam, penghapusan kredit bermasalah dan atau penjualan aktiva produktif lainnya, sehingga pendapatan bunga menjadi menurun, serta akan menurunkan NIM pada bank. 
Pada variabel Gross Domestic Product (GDP) growth terhadap net interest margin (NIM) menunjukkan hasil yang berkebalikan dengan hipotesis. Gross Domestic Product (GDP) growth terhadap net interest margin (NIM) menunjukkan pengaruh positif yang signifikan yaitu $t$. statistic > t tabel 2,9349>1,290). Hal ini mengindikasikan bahwa perkembangan aktivitas ekonomi yang baik yang dapat diketahui melalui pertumbuhan GDP positif, memicu tingginya permintaan akan kredit dan semakin sedikitnya kredit yang bermasalah maka marjin bank akan semakin tinggi sehingga akan berimbas terhadap meningkatnya NIM.

Pada variabel inflasi terhadap net interest margin (NIM) menunjukkan tidak berpengaruh signifikan yaitu $\mathrm{t}$. statistic $<\mathrm{t}$ tabel $(|-0,5184|<1,290)$. Hal ini mengindikasikan bahwa apabila bank lambat dalam menyesuaikan suku bunganya, maka akan menghasilkan peningkatan biaya (bunga) yang lebih cepat dibanding peningkatan keuntungan.

\section{Uji Koefisien Determinasi $\left(\mathrm{R}^{2}\right)$}

Uj1 Koefısıen Determınası $\left(K^{*}\right)$

\begin{tabular}{|l|c|c|c|}
\hline R-squared & 0.05068 & Mean dependent var & 1.258052 \\
\hline $\begin{array}{l}\text { Adjusted } \\
\text { R-squared }\end{array}$ & 0.026646 & S.D. dependent var & 0.775769 \\
\hline $\begin{array}{l}\text { S.E. of } \\
\text { regression }\end{array}$ & 0.766178 & Sum squared resid & 92.75055 \\
\hline F-statistic & 2.108711 & Durbin-Watson stat & 1.843541 \\
\hline $\begin{array}{l}\text { Prob(F- } \\
\text { statistic) }\end{array}$ & 0.082206 & Sumb. 2017 \\
\hline \multicolumn{4}{|c|}{ Sumber: Olah data Eviews, 2017 } \\
\hline
\end{tabular}

Dari tabel 8 diatas bahwa variabel

NIM mampu dijelaskan oleh variabel NPL, CAR, GDP growth, dan Inflasi. Jika $\mathrm{R}^{2}=0.05068$ artinya bahwa garis regresi menjelaskan $5,07 \%$ fakta, sedangkan sisanya sebesar 94,93\% dijelaskan oleh variabel residual yaitu variabel di luar model yang tidak dimasukkan dalam model.

\begin{tabular}{|c|c|c|c|}
\hline \multicolumn{4}{|c|}{ Ringkasan Pengujian Hipotesis } \\
\hline \multirow{2}{*}{ Hipotesis } & \multicolumn{2}{|l|}{ Hasil } & \multirow{2}{*}{ Kesimpulan } \\
\hline & Signifikansi & Arah & \\
\hline 1 (NPL) & Signifikan (pada $\alpha=10 \%$ ) & Positif & Terima H1 \\
\hline 2 (CAR) & Tidak Signifikan & Negatif & Tolak H2 \\
\hline 3 (GDP) & Signifikan (pada $\alpha=10 \%$ ) & Positif & Tolak H3 \\
\hline 4 (INF) & Tidak Signifikan & Negatif & Tolak H4 \\
\hline
\end{tabular}

\section{Pembahasan}

Hipotesis 1 menduga bahwa credit risk (NPL) berpengaruh positif terhadap net interest margin (NIM). Dan hasil penelitian menunjukkan bahwa hipotesis 1 terdukung, dimana credit risk yang diproksikan dengan non performing loan (NPL) berpengaruh positif signifikan terhadap net interest margin (NIM). Hal ini mengindikasikan bahwa semakin besar risiko kredit yang dihadapi bank, maka bank tersebut cenderung mendefinisikan margin bunga bersih yang tinggi juga.

Hipotesis 2 menduga bahwa risk aversion (CAR) berpengaruh positif terhadap net interest margin (NIM). Sedangkan hasil penelitian menunjukkan bahwa risk aversion yang diproksikan dengan capital adequacy ratio (CAR) tidak berpengaruh signifikan terhadap net interest margin (NIM) sehingga hipotesis 2 tidak terdukung. Hal ini mengindikasikan bahwa kenaikan rasio permodalan suatu bank bukan disebabkan karena adanya penambahan modal baru, tetapi pada umumnya karena disebabkan adanya penurunan risiko kredit sebagai dampak dari pelunasan kredit yang dilakukan peminjam, penghapusan kredit bermasalah dan atau penjualan aktiva produktif lainnya, sehingga pendapatan bunga menjadi menurun, serta akan menurunkan NIM pada bank.

Dilihat dari hasil uji analisis statistik deskriptif menunjukkan CAR pada perbankan yang terdaftar di BEI periode 2013-2016 rata-rata (mean) sebesar 18,8992 dengan standar deviasi sebesar 5,31733. CAR tertinggi yaitu 48,38 dimiliki oleh Bank Nationalnobu Tbk dan yang terendah yaitu 8,02 dimiliki oleh Bank Pembangunan Daerah Banten Tbk. 
Hipotesis 3 menduga bahwa Gross Domestic Product (GDP) berpengaruh negatif terhadap net interest margin (NIM). Sedangkan hasil penelitian menunjukkan bahwa Gross Domestic Product (GDP) berpengaruh positif signifikan terhadap net interest margin (NIM) sehingga hipotesis 3 tidak terdukung. Hal ini mengindikasikan bahwa perkembangan aktivitas ekonomi yang baik yang dapat diketahui melalui pertumbuhan GDP positif, memicu tingginya permintaan akan kredit dan semakin sedikitnya kredit yang bermasalah maka marjin bank akan semakin tinggi sehingga akan berimbas terhadap meningkatnya NIM.

Dilihat dari hasil uji analisis statistik deskriptif menunjukkan GDP growth pada perbankan yang terdaftar di BEI periode 2013-2016 rata-rata (mean) sebesar 5,1850 dengan standar deviasi sebesar 0,24285. GDP growth tertinggi yaitu 5,58 dan yangterendah yaitu 4,94.

Hipotesis 4 menduga bahwa inflasi berpengaruh negatif terhadap net interest margin (NIM). Sedangkan hasil penelitian menunjukkan bahwa inflasi tidak berpengaruh signifikan terhadap net interest margin (NIM) sehingga hipotesis4 tidak terdukung. Hal ini mengindikasikan bahwa apabila bank lambat dalam menyesuaikan suku bunganya, maka akan menghasilkan peningkatan biaya (bunga) yang lebih cepat dibanding peningkatan keuntungan.

Hasil uji analisis statistik deskriptif menunjukkan inflasi (X4) pada perbankan yang terdaftar di BEI periode 2013-2016 rata-rata (mean) sebesar 5,7775 dengan standar deviasi sebesar 2,60289. Inflasi tertinggi yaitu 8,38 dan yang terendah yaitu 3,02 .

\section{KESIMPULAN DAN SARAN}

\section{Kesimpulan}

1. Credit Risk (NPL) secara parsial berpengaruh signifikan terhadap
Net Interest Margin (NIM) pada perbankan yang terdaftar di Bursa Efek Indonesia periode 2013-2016. Hal ini dibuktikan dengan adanya nilai $\mathrm{t}$. statistic > t tabel $(1,4136>$ 1,290). Sehingga hal ini mengindikasikan bahwa semakin besar risiko kredit yang dihadapi bank, maka bank tersebut cenderung mendefinisikan margin bunga bersih yang tinggi juga.

2. Risk Aversion (CAR) secara parsial tidak berpengaruh signifikan terhadap Net Interest Margin (NIM) pada perbankan yang terdaftar di Bursa Efek Indonesia periode 2013- 2016, yaitu hal ini mengindikasikan bahwa kenaikan rasio permodalan suatu bank bukan disebabkan karena adanya penambahan modal baru, tetapi pada umumnya karena disebabkan adanya penurunan risiko kredit sebagai dampak dari pelunasan kredit yang dilakukan peminjam, penghapusan kredit bermasalah dan atau penjualan aktiva produktif lainnya, sehingga pendapatan bunga menjadi menurun, serta akan menurunkan NIM pada bank.

3. Gross Domestic Product (GDP) growth secara parsial berpengaruh signifikan terhadap Net Interest Margin (NIM) pada perbankan yang terdaftar di Bursa Efek Indonesia periode 2013-2016. Hal ini dibuktikan dengan adanya nilai t. statistic > t tabel (2,9349 > 1,290). Sehingga hal ini mengindikasikan bahwa perkembangan aktivitas ekonomi yang baik yang dapat diketahui melalui pertumbuhan GDP positif, memicu tingginya permintaan akan kredit dan semakin sedikitnya kredit yang bermasalah maka marjin bank akan semakin tinggi sehingga akan berimbas terhadap meningkatnya NIM. 
4. Inflasi secara parsial tidak berpengaruh signifikan terhadap Net Interest Margin (NIM) pada perbankan yang terdaftar di Bursa Efek Indonesia periode 2013-2016, yaitu hal ini mengindikasikan bahwa apabila bank lambat dalam menyesuaikan suku bunganya, maka akan menghasilkan peningkatan biaya (bunga) yang lebih cepat dibanding peningkatan keuntungan.

\section{DAFTAR PUSTAKA}

Ayuningrum, Anggrainy Putri. 2011. "Analisis Pengaruh CAR, NPL, BOPO, NIM dan LDR terhadap ROA” Skripsi Universitas Diponegoro Semarang.

Dendawijaya, Lukman. 2005. Manajemen Perbankan. Jakarta. Ghalia Indonesia.

Dewi, Indah lestari, dan Triaryati Nyoman. 2017. "Pengaruh factor internal dan eksternal Bank terhadap net interest margin di Indonesia" E-jurnal Manajemen Unud, Vol.6, No.6.

Ghozali, Imam. 2006. Aplikasi Analisis Multivariat. Semarang: Badan Penerbit Universitas Diponegoro.

Hidayat Taufik, Hamidah, dan Mardiyati Umi. 2012. "Analisis pengaruh karakteristik bank dan inflasi terhadap net interest margin Studi Kasus Pada Bank Konvensional yang Terdaftar di Bursa Efek Indonesia Tahun 2006-2010" Jurnal Riset Manajemen Sains Indonesia (JRMSI) |Vol. 3, No. 1, 2012.

Hismendi, Hamzah Abubakar, dan Musnadi Said. 2013. "Analisis pengaruh nilai tukar, SBI, inflasi dan pertumbuhan GDP terhadap pergerakan indeks harga saham gabungan di Bursa Efek Indonesia" Jurnal Ilmu Ekonomi Pascasarjana Universitas Syiah Kuala.

http://www.bi.go.id/id/publikasi/laporanta hunan/perekonomian/Pages/LPI_201 6.aspx.Diakses tanggal 20 Juli 2017 pada pukul 19.50 WIB.

https://www.bps.go.id/linkTabelStatis/vie w/id/907. Diakses tanggal 8 November 2017 pada pukul 10.40 WIB

https://www.sahamok.com/emiten/sektorkeuangan/sub-sektor-bank/. Diakses tanggal 26 September 2017 pada pukul 13.35 WIB.

Kasmir. 2012. Bank dan Lembaga Keuangan Lainnya. Jakarta. PT Raja Grafindo Persada.

Lestari, Henny Setio, dan Aprilriani Giya. 2016. "Pengaruh factor internal dan eksternal bank terhadap kinerja keuangan pada bank umum di Indonesia" Jurnal Manajemen Bisnis, Vol. 11, No. 2, Juli - Desember 2016.

Puspitasari, Elisa. 2014. "Analisis faktorfaktor yang mempengaruhi net interest margin pada bank-bank umum di Indonesia" Jurnal Ilmu Manajemen, Volume 2 Nomor 4 Oktober.

Raharjo, Pamuji Gesang. 2014. "Faktor Determinan Marjin Bunga Bersih Bank Pembangunan Daerah Indonesia" Jurnal Keuangan dan Perbankan, Vol.18, No.1 Januari 2014, hlm. 105-119.

Robert, Safitri Ervita, dan Cholid Idham. 2015. "Pengaruh Gowth, NPL, NIM terhadap profitabilitas Bank Domestik dan Bank Asing di Indonesia" Jurnal Jurusan Manajemen STIE MDP, Palembang. 
Rustam, Bambang Rianto. 2013. Manajemen Risiko Perbankan Syariah di Indonesia. Jakarta. Salemba Empat.

Sidabalok, L.R. \& Viverita. 2011. The Determinants of Net Interest Margin in the Indonesian Banking Sector. Research Paper, 13(2).

Sugiyono. 2009. Metodologi Penelitian Bisnis. Bandung: Alfabeta Taswan. 2010. Manajemen Perbankan Konsep, Teknik dan Aplikasi. Yogyakarta. UPP STIM YKPN.

Widarjono, A. 2013. Ekonometrika. UPP STIM YKPN. Yogyakarta. 